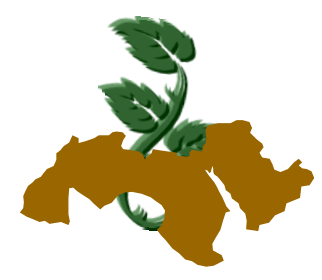

\title{
EFFECT OF NITROGEN SOURCES AND CYSTEINE ON THE PRODUCTIVITY OF SOME WHEAT VARIETIES
}

\author{
Salem ${ }^{1}$, M.S.A., N.I., Darwish ${ }^{1}$, O.M. Saad El-Dein Harb ${ }^{1}$ and S.I. Abo-Remaila ${ }^{2}$ \\ 1- Agron. Dept. Fac. Agric. Al-Azhar Univ., Cairo, Egypt \\ 2- Ministry of Agric. Giza, Egypt \\ Email: Ilsalahll@yahoo.com
}

Keywords: Cysteine, Nitrogen source, Wheat variety, Productivity, Cereialeine, Biogene, Biofertilizer

\section{ABSTRACT}

Three experiments for to pot ond one field experiment were carried out at Agric. Res. Station, Fac. Agric., Al-Azhar Univ. Nasr City and El-Aklag region, Kaliobia Governorate, Egypt, during $2011 / 2012,2012 / 2013$ and $2013 / 2014$ to investigate the influence of mineral nitrogen fertilizer and biological ones i.e. Cerialen and Biogen under foliar spraying with Cysteine on the productivity of three wheat varieties (Sakha-93. Masry-1 and Banisweif). The studied treatments were recommended dose of $\mathrm{N}$ (75 kg N/fed., F1), recommended dose of $\mathrm{N}$. fertilizer + Cysteine at the rate of 150 ppm (F2) $50 \%$ recommended dose of $\mathrm{N}$ fertilizer + Cerialine + Cysteine (F3) and 50\% recommended dose of $\mathrm{N}$ fertilizer + biogen + Cysteine (F4).

Complete randomized design was applied for the pot experiments, whereas split plot design was conducted for the experimental field.

The results revealed that the difference between the investigated varieties due to plant height $(\mathrm{cm})$ and flag leaf area $\left(\mathrm{cm}^{2}\right)$ was substantial. Sakha-93 var. pronounced its superiority due to the both studied growth characters during the pot and field experiment.

F2 treatment located the first order and gave the tallest wheat plants, whereas F4 treatment awarded the largest area of flag leaf, during the three experimental seasons.

Yield and yield components parameters (No of grains/spike, 1000-grain weight (g), grain yield (g/plant in pots and ardab/fed. in field), straw yield (g/plant and ton/fed. in field) and biological yield (g/plant in pots and ton/fed. in field ) differed significantly between varieties. the maximum value were obtained from Sakha-93 and Masry-1, while the minimum ones associated with Baniswif variety, through the three experimental seasons. With the exception of straw yield either pot experiments or the field one,

F2 and F4 treatments resulted in the heighest data for the previous yield and yield components parameters. The effect for the first order interaction (Var. x Fert.) on the studied characters differed with the characters difference (significant or nonsignificant) as shown from the obtained results during the three experimental seasons.

\section{INTRODUCTION}

In Egypt, wheat is considered as one of the main and strategic crop that caused a complicated problem especially the heigh gab between production and consumption, the local production equal $40 \%$ whereas the importing equals $60 \%$ roughly from our requirements.

Many researches and attempts were carried out to overcome this problem in the recent years by the application of nitrogen biological fertilizer beside the mineral one to reduce the cost, the additive amount of mineral fertilizer and environmental pollution.

Nitrogen fertilizer plays an important role in improving the physical and mechanical properties of the soil beside it,s positive impact on plant growth and production. Mandour et al (1986). found that, the increases of chemical constituents in the plant by the increases of mineral fertilizer is attributed to nitrogen enhances the capacity of the plants to 
absorb nutrients by the increases of root surface/unit of soil volume, as well as the heigh capacity of the plants supported with nitrogen in building metabolism, which in turn contribute much to the enhancement of nutrient uptake.

Favilli et al (1987), declared that bio fertilizer are more effective than applying manure or synthetic fertilizers. Bio fertilizer inoculations can lower $\mathrm{N}$ fertilizer requirements up to $35 \%$, as $\mathrm{N}$ utilization in inoculated plants becomes more efficient. On the other hand, Hussein et al (1987), reported that, the chemical fertilizers are richer in their nutrient contents, less bulky, easier to transport and apply in the field, thus show quick response on crop in turn of grain yield.

Using of amino acid as foliar spray on plants is a modern technique for improving growth and yield.

Cysteine bio synthesis plays a central role in fixing inorganic sulfur from the environment provides the only metabolic sulfide donor for the generation of methionine, phtochelatins, iron-sulfur cluster, vitamin factors and multiple secondary metabolites (Bonner et al 2005).

On the same line Haas et al (2008) recorded that, Cysteine, synthesis in plants is a fundamental process for protein biosynthesis and all anabolic pathways that requires reduced sulfur. Bacteria is able to reduce sulfate by assimilatory sulfate reduction to sulfide and to integrate it into Cysteine.

In the Cytcol. For emphases the relation between Cysteine and the sulfur reduction pathway in plants Noctor and Foyer (1998) stated that, the Cysteine. formed serves as a precursor for the synthesis of various sulfur containing metabolites, of which glutathione (GSH) represents the major storage and transport form of reduced sulfur.

With regard to the various responses of the different wheat varieties to mineral or bio nitrogen fertilizer and Cysteine. foliar spray, that owing to wheat varieties differed in growth characters as reported by Abdallah \& Bassiouny, (1997) and Abel-Ati \& Zaki (2006).

Zaki and Radwan (2011), in Sinai found that, soil inoculation with Azotobacter chroococum (NB) and amendment of soil with farmyard manure (FYM), at the rate of $10 \mathrm{ton} / \mathrm{fed}$. in combination with foliar spray of organic acid at the rate of 150 $\mathrm{mg} / \mathrm{L}$ increased wheat yield and its components as well as, improved the nutritional status and quality of wheat grown on a newly reclaimed soil.

The target of this research is to investigate the effect of two sources of nitrogen fertilizer (mineral and biological) in a combination with amino acid
Cysteine on the growth, yield and yield components of some wheat varieties.

\section{MATERIALS AND METHODS}

Two pot experiments were conducted during 2011/2012 and 2012/2013 in Agric. Res. Station, Fac. Agric. Al-Azhar Univ. Nasr City, Cairo and one field experiment was carried out in El-Aklag region, Kaliobia governorate, Egypt, during 2013/2014, to illustrate the effect of mineral and bionitrogen fertilizer in combination with Cysteine (Cys) as amino acid foliar spray on growth and yield as well as yield components of three wheat varieties (Sakha93, Masry-1 and Baniswif-6) that were obtained from wheat Res. Inst. Agric. Res. Center, Giza, Egypt.

\section{A) First: The pot experiment}

\section{The studied treatments}

1. The recommended dose of $\mathrm{N}$. fertilizer $(75 \mathrm{~kg}$ $\mathrm{N} / \mathrm{fed}$.) as control (F1)

2. Cysteine foliar spray $+75 \mathrm{~kg} \mathrm{~N} / \mathrm{fed}$. (F2)

3. Cereialeine $+37.5 \mathrm{~kg} \mathrm{~N} / \mathrm{fed} .(50 \%)+$ Cysteine foliar spray

4. Biogene + $37.5 \mathrm{~kg} \mathrm{~N} / \mathrm{fed}$. (50\%) + Cysteine foliar spray

These studied treatments were arranged in complete randomized with three replications where the number of pots was 36 . The pot or the experimental unit was a plastic pouch, it's high equals 52 $\mathrm{cm}$, it is circumference equals $78 \mathrm{~cm}$ and the surface area of pot equals $0.1074 \mathrm{~cm}^{2}$.

Each one contained $75 \mathrm{~g}$ from composed that was added as a general organic fertilizer beside the different weights from the studied treatments. Mineral nitrogen fertilizer was added as Ammonium Nitrate $33.5 \%$ at the rate of $207 \mathrm{~g}$ for each pot. Whereas cerialeine (Bacillus polymexa) or biogen (Azotobacter sp.) as biofertilizer were mixed with wheat grains at the rate of $0.5 \mathrm{~g}$ before sowing.

Bio fertilizers(cerialein and biogen)are produced and distributed commercially by General organization for Agriculture Equalion fund (GOAEF), ministry of Agiculture and land Reclamation, Egybt. Super phosphate was added at the rate of $1.87 \mathrm{~g}$ for each pot according to the recommended dose (150 kg/fed.) whereas potassium sulphate was applied at the rate of $0.51 \mathrm{~g}$ for each one according to the recommended dose (50kg/fed.). Each pot contained 5 plants according 
to the optimum rate for the number of grains equals 90 plant $/ \mathrm{m} 2$.

Irrigation was applied according to the determination of field capacity where the pots irrigated every 15 days till saturation.

To avoid the lossing of any amount of the additive fertilizer with irrigation water, plastic plates were put under every pot for saving the homogeneous between the experimental units due to the amount of water and the distribution of the different fertilizers.

Cysteine as foliar spray at the rate of $150 \mathrm{ppm}$ was applied twice; the first stage at the beginning of vegetative growth after 25 days from sowing date, whereas the second one at the existance of the flag leaf after 75 days from the sowing day.

Table (1) cleared the chemical analysis of that used composed. The sowing date was on the 20 of November in 2011/2012 and on the 22 of November in 2012/2013 season.

Table 1. Chemical analysis of the applied compost during the three growing seasons

\begin{tabular}{|cccc|}
\hline Determination & $\begin{array}{c}\text { The pot experiments } \\
\text { during }\end{array}$ & $\begin{array}{c}\text { The field } \\
\text { experiments } \\
\text { during }\end{array}$ \\
\hline pH & $\mathbf{2 0 1 1 / 2 0 1 2}$ & $\mathbf{2 0 1 2 / 2 0 1 3}$ & $\mathbf{2 0 1 3 / 2 0 1 4}$ \\
O.M & 7.8 & 7.7 & 7.6 \\
EC(dsm-1) & 38.11 & 38.33 & 36.45 \\
$\mathbf{C} / \mathbf{N}$ & 4.71 & 4.65 & 5.13 \\
$\mathbf{N} \%$ & 14.8 & 14.72 & 15.28 \\
$\mathbf{P} \%$ & 1.48 & 1.51 & 1.43 \\
$\mathbf{K} \%$ & 0.55 & 0.56 & 0.54 \\
Fe (ppm) & 0.45 & 0.45 & 0.46 \\
Cu (ppm) & 1.25 & 1.28 & 1.27 \\
Zn (ppm) & 1.58 & 1.62 & 1.59 \\
Mn (ppm) & 1.82 & 188 & 1.91 \\
\hline
\end{tabular}

\section{B) The field experiment}

The studied treatments: They were similar to those obtained in the pot experiments.

The split plot design with three replications was used in this experiment, whereas the tested wheat verities were allocated in the main pots. The area of each plot was $56 \mathrm{~m}^{2}(16 \mathrm{~m} \times 3.5 \mathrm{~m})$ and the four studied treatments of each experiment were devoted in the sub plots $14 \mathrm{~m}^{2}(3.5 \mathrm{~m} \times 4 \mathrm{~m})$ for each.

The recommended dose of nitrogen $(75 \mathrm{~kg}$ $\mathrm{N} / \mathrm{fed}$.) and the half one (37.5kg N/fed) were added as ammonium nitrate $33.5 \%$. phosphorus fertilizer was applied at the rate of $150 \mathrm{~kg} / \mathrm{fed}$. $(15.5 \%$
P205), while potassium one was experimented at the rate of $50 \mathrm{kgk} / \mathrm{fed}$. $\left(48.8 \% \mathrm{k}_{2} \mathrm{O}\right)$, they were applied before sowing.

Table (2) shows the mechanical and chemical properties of the experimental soil.

Biogen (Aztobacter Sp) and Cerialeine (Bucillus Polymexa) were added at the rate of 4 pouches/fed. mixing with grain before sowing.

Cysteine as foliar spray at the rate of $150 \mathrm{ppm}$ was applied at the same plant stage of the pot experiment $(200 \mathrm{~L} / \mathrm{fed})$.

Sowing date was on the 28 of November in 2013/2014 season.

Table 2. Some physical and chemical analysis of the experimental sites during the three growing seasons

\begin{tabular}{|c|c|c|c|}
\hline \multirow[t]{2}{*}{ Soil analysis } & \multicolumn{2}{|c|}{$\begin{array}{c}\text { The pot experiments } \\
\text { during }\end{array}$} & \multirow{2}{*}{$\begin{array}{c}\begin{array}{c}\text { The field } \\
\text { experiments } \\
\text { during }\end{array} \\
2013 / 2014\end{array}$} \\
\hline & 2011/2012 & $2012 / 2013$ & \\
\hline $\begin{array}{l}\text { A-Physical } \\
\text { analysis: } \\
\text {-particle size } \\
\text { distribution: }\end{array}$ & & & \\
\hline Sand\% & 77.65 & 76.9 & 72.7 \\
\hline Clay\% & 10.35 & 10.8 & 14.1 \\
\hline Silt\% & 12 & 12.3 & 13.2 \\
\hline \multicolumn{4}{|l|}{$\begin{array}{l}\text { B-Chemical } \\
\text { analysis: } \\
\text {-catins(mg/L) }\end{array}$} \\
\hline $\mathrm{Na}^{++}$ & 2.6 & 2.4 & 1.88 \\
\hline $\mathbf{M g}^{++}$ & 1.3 & 1.2 & 1.0 \\
\hline $\mathrm{Ca}^{++}$ & 1.5 & 1.4 & 2.0 \\
\hline \multicolumn{4}{|l|}{-Anins(mg/L). } \\
\hline $\mathrm{CL}^{-}$ & 1.91 & 1.88 & 1.5 \\
\hline $\mathrm{So}_{4}^{--}$ & 2.6 & 2.71 & 2.23 \\
\hline $\mathrm{HCO} 3$ & 1.8 & 1.82 & 1.6 \\
\hline $\mathrm{CO} 3$ & 0.0 & 0.0 & 0.0 \\
\hline pH & 7.4 & 7.3 & 8.2 \\
\hline$E C(d s m-1)$ & 0.72 & 0.78 & 0.4 \\
\hline $\mathrm{Cu}^{+}(\mathrm{ppm})$ & 0.6 & 0.52 & 0.48 \\
\hline $\mathrm{Zn}^{++}$ & 0.65 & 0.72 & 0.92 \\
\hline $\mathrm{Mn}^{++}$ & 4.2 & 4.3 & 6 \\
\hline $\mathrm{Fe}^{++}$ & 1.87 & 1.92 & 1.1 \\
\hline $\begin{array}{l}\text { Available } N \\
\quad \text { (ppm) }\end{array}$ & 15 & 15 & 15 \\
\hline $\begin{array}{l}\text { Available P } \\
\text { (PPm) }\end{array}$ & 137 & 135 & 140 \\
\hline $\begin{array}{l}\text { Available K } \\
\text { (PPm) }\end{array}$ & 728 & 720 & 604 \\
\hline Texture & $\begin{array}{l}\text { Sandy } \\
\text { loan }\end{array}$ & Sandy loan & Sandy loan \\
\hline
\end{tabular}




\section{The studied characteristics}

\section{A) Growth character}

In both experiments five plants were choosen randomly to estimate:

1) Plant height, in $\mathrm{cm}$, it was calculated after booting stage.

2) Flag leaf area, in $\mathrm{cm}^{2}$, it was estimated after flowering stage.

\section{B) Yield and yield components}

At harvesting time the same plants were harvested to determine:

1. No. of grains/spike.

2. 1000-grain weight $(\mathrm{g})$.

3. Grain yield ( $g /$ plant in pot and ardab/fed. in field).

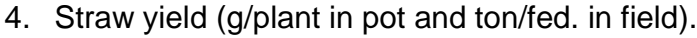

5. Biological yield (g/plant in pot and ton/fed. in field).

\section{Statistical analysis}

The complete randomize design with three replications for the pot experiments and the split plot design with three replications also for the field experiment, as well as factorial arrangement were used. The obtained results subjected to statisticale analysis according to procedure outlined by Snedecor and Cochran (1981). Means were compared using the least significant differences (L.S.D) test at $5 \%$ level of probability.

\section{RESULTS AND DISCUSSION}

Data in Table (3) explicated that the difference between the studied wheat varieties due to plant height $(\mathrm{cm})$ and flag leaf area $\left(\mathrm{cm}^{2}\right)$ was significant. In pot and field experiments Sakha-93 var. pronounced it's superiority due to plant height (72.61, 73.26 and $77.37 \mathrm{~cm}$ ) for 2011/2012, $2012 / 2013$ and 2013/2014 seasons, respectively, as enduring with the other tested varieties in the field experiment. Flag leaf area results followed the same trend where Masry -1 var. was a strong emulative $\left(64.98 \mathrm{~cm}^{2}\right)$ to Sakha-93 var. $(64.87 \mathrm{~cm} 2)$, the difference between them was not significant, whereas Baniswif- 6 var. awarded the lowest significant values for the both studied parameters. These results are in accordance with those reported by Abd-Allah and Bassiouny (1997).
With regard to the significant impact of nitrogen fertilizer on the previous studied parameters, the treatment of (75 kg N/fed. + 150 ppm Cysteine) F2 gave the tallest plants, it was followed by the application of $75 \mathrm{~kg} \mathrm{~N} / \mathrm{fed}$. (F1).

F2 treatment was exceeded by $3.05 \%$ as compared with F4 treatment which resulted in the shortest plants, in the first season. Same trend was detected in the second one, as well as in the field experiment. Whereas $(37.5 \mathrm{~kg} \mathrm{~N} / \mathrm{fed}+$ biogen + Cysteine) F4, was more effective and awarded the maximum area of flag leaf, it increased that area by $1.8 \%$ as enduring with control treatment $(\mathrm{F} 1)$, in the first season. Similar observations had been achieved in the second one and field experiment.

As for the significant effect of $(F \times V)$ interaction, treating Sakha-93 plants with F2 treatment scored the tallest plants $(73.68 \mathrm{~cm})$ in the first season, similar results were obtained from the second one and field experiment. Whereas treating Sakha93 plants with $\mathrm{F} 4$ treatment recorded the greatest flag leaf area $\left(67.51 \mathrm{~cm}^{2}\right)$ in the first season, the second one and field experiment followed the same trend.

These results may be ought to the beneficial effect of Azotobacter on wheat is due to not only to nitrogen fixation but also to altering the microbial balance, suppressing pathogenic microorganisms, mobilization soil Sulphate and providing promoting substances that stimulated plant development as advocated by Eweda and Viassak (1988) and Malik and Bilal (1988).

Regarding to yield and yield components, No. of grain/spike, 1000-grain weight (g), grain yield ( $\mathrm{g}$ in pot and ardab in field), straw yield ( $g$ in pot. and ton in field) and biological yield ( $g$ in pot and ton in field) were significantly affected by the difference between the studied varieties. Masry-1 Var. located the first order due to No. of grains/spike, seed index and grain yield.

It was exceeded by $6.01,24.58$ and $16.46 \%$ as comparing with Baniswief- 6 Var. which represented the third one, in the first season. Similar results were gained from the second season, as well as from the third season or field experiment.

These results are in accordance with those reported by Hassanein (2001), Ahmed et al (2006) and Zheng et al (2008), they announced that wheat cieultivars differed in yield and its components, grain, straw and biological yields with respect to, the different nitrogen sources under study, they had significant effect on the above studied parameters. 
Table 3. Plant height $(\mathrm{cm})$ and Flag leaf area $\left(\mathrm{cm}^{2}\right)$ of some Wheat varieties as affected by some Nitrogen fertilizer sources during 2011/2012, 2012/2013 and 2013/2014 seasons

\begin{tabular}{|c|c|c|c|c|c|c|c|}
\hline \multirow{2}{*}{\multicolumn{2}{|c|}{$\begin{array}{l}\text { character } \\
\text { Treatment } \\
\end{array}$}} & \multicolumn{3}{|c|}{ plant height (cm) } & \multicolumn{3}{|c|}{ Flag leaf area $(\mathrm{cm} 2)$} \\
\hline & & \multicolumn{2}{|c|}{ pot exp. } & \multirow{3}{*}{$\begin{array}{l}\text { field exp. } \\
2013 / 2014\end{array}$} & \multicolumn{2}{|c|}{ pot exp. } & \multirow{3}{*}{$\begin{array}{l}\text { field exp. } \\
2013 / 2014\end{array}$} \\
\hline wh. varieties & N.frt. & & & & & & \\
\hline$(\mathrm{W} . \mathrm{V})$ & $\begin{array}{c}\text { Package } \\
(f)^{\star}\end{array}$ & $2011 / 2012$ & $2012 / 2013$ & & $2011 / 2012$ & $2012 / 2013$ & \\
\hline \multirow[t]{4}{*}{ Sakha 93} & $f 1$ & 73.54 & 74.01 & 77.04 & 65.93 & 66.23 & 62.13 \\
\hline & f2 & 73.68 & 75.04 & 78.22 & 67.07 & 67.43 & 65.12 \\
\hline & f3 & 71.99 & 72.44 & 77.08 & 67.43 & 67.73 & 66.04 \\
\hline & $\mathrm{f} 4$ & 71.24 & 71.53 & 77.14 & 67.51 & 67.93 & 66.19 \\
\hline \multicolumn{2}{|c|}{ Mean } & 72.61 & 73.26 & 77.37 & 66.99 & 67.33 & 64.87 \\
\hline \multirow[t]{4}{*}{ Masry 1} & $f 1$ & 69.88 & 70.58 & 75.89 & 63.98 & 64.30 & 63.04 \\
\hline & f2 & 71.24 & 71.98 & 76.92 & 65.27 & 65.64 & 65.33 \\
\hline & f3 & 69.34 & 69.58 & 76.11 & 65.59 & 65.98 & 65.71 \\
\hline & $\mathrm{f4}$ & 68.53 & 68.70 & 76.15 & 65.88 & 66.09 & 65.86 \\
\hline \multicolumn{2}{|c|}{ Mean } & 69.75 & 70.21 & 76.27 & 65.18 & 65.50 & 64.98 \\
\hline \multirow[t]{4}{*}{ Bani swif 6} & $\mathrm{f1}$ & 67.12 & 67.59 & 72.92 & 62.44 & 62.74 & 56.03 \\
\hline & f2 & 67.69 & 70.84 & 74.02 & 63.45 & 63.76 & 59.00 \\
\hline & f3 & 66.41 & 66.66 & 73.11 & 63.64 & 64.07 & 59.58 \\
\hline & $\mathrm{f} 4$ & 66.54 & 66.79 & 73.18 & 63.77 & 64.08 & 59.73 \\
\hline \multicolumn{2}{|c|}{ Mean } & 66.94 & 67.97 & 73.31 & 63.32 & 63.66 & 58.59 \\
\hline \multicolumn{8}{|c|}{ General means of } \\
\hline & $\mathrm{f1}$ & 70.18 & 70.73 & 75.28 & 64.12 & 64.42 & 60.40 \\
\hline & f2 & 70.87 & 72.62 & 76.39 & 65.26 & 65.61 & 63.15 \\
\hline & f3 & 69.25 & 69.56 & 75.43 & 65.55 & 65.93 & 63.78 \\
\hline & $\mathrm{f} 4$ & 68.77 & 69.01 & 75.49 & 65.72 & 66.03 & 63.93 \\
\hline \multicolumn{8}{|c|}{ LSD at $5 \%$} \\
\hline \multirow{3}{*}{\multicolumn{2}{|c|}{$\begin{array}{c}\text { N.fertilizer(f) } \\
\text { Varieties ( V ) } \\
\mathrm{f} \times \mathrm{V}\end{array}$}} & 1.04 & 1.11 & 0.72 & 1.17 & 1.13 & 1.04 \\
\hline & & 0.90 & 0.96 & 0.96 & 1.01 & 0.98 & 1.14 \\
\hline & & N.S & N.S & N.S & N.S & N.S & N.S \\
\hline
\end{tabular}

In the first season (pot experiment), the application of ( $37.5 \mathrm{~kg} \mathrm{~N} / \mathrm{fed}+$ Cerialeine + Cysteine) $\mathrm{F}_{3}$ treatment resulted in the highest no. of grains/spike (44.10 grains/spike), the maximum weight of 1000 grains $(53.73 \mathrm{~g})$ and the greatest yield of straw $(16.40 \mathrm{~g})$, whereas the lowest values associated with $\mathrm{F}_{1}$ or control treatment.

In the second and third seasons, most of the results followed the same trend with the exception of, the results of field experiment which declared that $F_{2}$ treatment $(75 \mathrm{~kg} \mathrm{~N} / \mathrm{fed}$. + Cysteine) gave the highest no. of grains/spike (41.80 grains/spike), straw yield (4.12 ton/fed.) and biological yield (6.49 ton/fed).
On the other hand, in the first season grain yield and biological yield was increased significantly by the application of $\mathrm{F}_{4}$ treatment $(37.5 \mathrm{~kg} \mathrm{~N} / \mathrm{fed}$. + Biogen +Cysteine) as enduring with $\mathrm{F}_{1}$ or control treatment. Similar results had been achieved in the second and third seasons as shown in Table (5).

These results may be due to that inoculation of wheat grains with biofertilizer increased supply of plant hormones (auxins, cytokinins and gibberellins) by the microorganism or by roots as a result of reaction to microbial colonization, as explicated by Auivi and Feldman (1982).

On the same line, El-Hadaad et al (1986) concluded that the beneficial effect of monosymbiotic fixing bacteria besides increasing wheat yield is it's reduction of $\mathrm{N}$ fertilization by up $50 \%$. 
Table 4. Number of spikes/plant and 1000-grain weight (g) of some wheat varieties as affected by some Nitrogen fertilizer sources during 2011/2012, 2012/2013 and 2013/2014 seasons

\begin{tabular}{|c|c|c|c|c|c|c|c|}
\hline \multirow{2}{*}{\multicolumn{2}{|c|}{$\begin{array}{l}\text { character } \\
\text { Treatment }\end{array}$}} & \multicolumn{3}{|c|}{ No. of grains /spike } & \multicolumn{3}{|c|}{1000 - grain weight $(\mathrm{g})$} \\
\hline & & \multicolumn{2}{|c|}{ pot exp. } & \multirow{2}{*}{$\begin{array}{l}\text { field exp. } \\
2013 / 2014\end{array}$} & \multicolumn{2}{|c|}{ pot exp. } & \multirow{2}{*}{$\begin{array}{r}\text { field exp. } \\
2013 / 2014\end{array}$} \\
\hline $\begin{array}{c}\text { wh.varieties } \\
\text { (W.V) }\end{array}$ & $\begin{array}{c}\text { N.frt. } \\
\text { Package } \\
(f)^{\star}\end{array}$ & $2011 / 2012$ & $2012 / 2013$ & & 2011/2012 & 2012/2013 & \\
\hline \multirow{4}{*}{ Sakha 93} & $f 1$ & 42.99 & 42.02 & 40.50 & 47.40 & 47.47 & 38.07 \\
\hline & f2 & 43.18 & 43.12 & 42.09 & 50.97 & 51.50 & 39.90 \\
\hline & f3 & 43.67 & 43.52 & 41.44 & 56.83 & 57.47 & 41.00 \\
\hline & $\mathrm{f} 4$ & 43.46 & 43.59 & 41.50 & 57.80 & 57.93 & 41.37 \\
\hline \multicolumn{2}{|c|}{ Mean } & 43.32 & 43.06 & 41.38 & 53.25 & 53.59 & 40.08 \\
\hline \multirow{4}{*}{ Masry 1} & $\mathrm{f1}$ & 44.60 & 43.13 & 42.53 & 49.13 & 49.03 & 39.10 \\
\hline & f2 & 45.39 & 44.03 & 43.50 & 52.07 & 52.80 & 41.20 \\
\hline & f3 & 45.65 & 44.28 & 43.98 & 57.83 & 57.23 & 42.13 \\
\hline & $\mathrm{f} 4$ & 45.48 & 44.34 & 44.04 & 58.47 & 57.83 & 42.73 \\
\hline \multicolumn{2}{|c|}{ Mean } & 45.28 & 43.94 & 43.51 & 54.38 & 54.23 & 41.29 \\
\hline \multirow{4}{*}{ Bani swif 6} & $\mathrm{f} 1$ & 42.06 & 39.56 & 37.99 & 39.40 & 39.00 & 33.77 \\
\hline & f2 & 42.80 & 41.24 & 39.82 & 41.07 & 40.93 & 35.00 \\
\hline & f3 & 42.98 & 42.02 & 38.31 & 46.53 & 46.53 & 37.91 \\
\hline & $\mathrm{f} 4$ & 43.00 & 42.06 & 38.33 & 47.60 & 46.90 & 38.17 \\
\hline \multicolumn{2}{|c|}{ Mean } & 42.71 & 41.22 & 38.61 & 43.65 & 43.34 & 36.21 \\
\hline \multicolumn{8}{|c|}{ General means of } \\
\hline & $\mathrm{f} 1$ & 43.22 & 41.57 & 40.34 & 45.31 & 45.17 & 36.98 \\
\hline & f2 & 43.79 & 42.79 & 41.80 & 48.03 & 48.41 & 38.70 \\
\hline & f3 & 44.10 & 43.27 & 41.24 & 53.73 & 53.74 & 40.35 \\
\hline & $f 4$ & 43.98 & 43.33 & 41.29 & 54.62 & 54.22 & 40.76 \\
\hline \multicolumn{8}{|c|}{ LSD at $5 \%$} \\
\hline \multicolumn{2}{|c|}{ N.fertilizer(f) } & 0.68 & 0.41 & 0.68 & 0.64 & 0.60 & 0.92 \\
\hline \multicolumn{2}{|c|}{ Varieties ( V ) } & 0.59 & 0.35 & 0.54 & 0.55 & 0.52 & 0.65 \\
\hline \multicolumn{2}{|c|}{$f \times V$} & N.S & 0.71 & N.S & 1.10 & 1.05 & N.S \\
\hline
\end{tabular}

\footnotetext{
${ }^{\star}$ N.fertilizer packge.

f1= Reccom.N.rate

f2 $=$ Reccom.N.rate +cysteine

f3 $=\mathbf{5 0} \%$ of Reccom.N.rate+cerialen+cysteine

f4 $=50 \%$ Reccom.N.rate+biogen+cysteine
} 
Table 5. Grain yield, Straw yield and Biological yield of some Wheat varieties as affected by some Nitrogen fertilizer sources during 2011/2012, 2012/2013 and 2013/2014 seasons

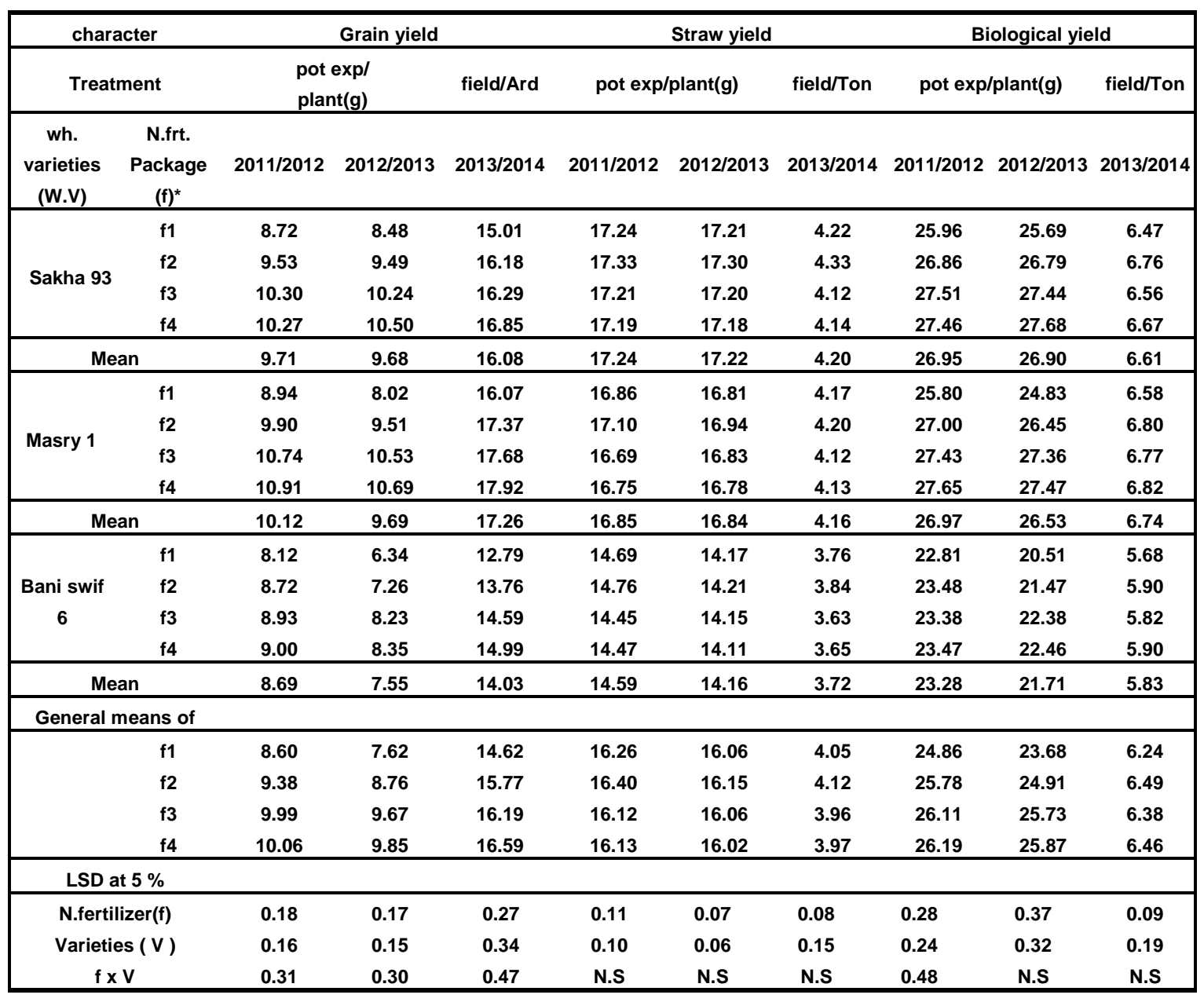

${ }^{\star} \mathrm{N}$.fertilizer packge. $\quad \mathrm{f1}=$ Reccom.N.rate

f3 $=50 \%$ of Reccom.N.rate+cerialen+cysteine

f4 $=50 \%$ Reccom.N.rate+biogen+cysteine

Eventually, most of $(F \times V)$ interaction had significant influence on yield and yield components. For example, grain yield that belongs to Masry-1 was enhanced significantly by treating with F3 (37.5 kg N/fed. + Cerialeine + Cysteine) either for pot experiments' or the field one.

\section{REFERANCES}

Abd-Alla, M.M. and Bassiouny, A.H. 1997. Response of two wheat cultivars to various planting densities. Egypt. J. Appl. Sci., 9(8): 836849.
Abd-el-Ati, A.A. and Zaki, K.I. 2006. Productivity of some wheat cultivars in calcareous soils under organic farming and rainfed conditions with special references to plant disease. J. Agric. Sci., Mansoura Univ., 31(4): 1875-1889.

Ahmed, A.G., Hassnain, M.S. and El-Gazar, M.M. 2006. Growth and yield response of two wheat cultivars to complete foliar fertilizer compound "Dogoplas". J. Appl. Sci. Res., 2(1): 2026.

Avivi, Y. and Feldman, M. 1982. The response of wheat to bacteria of genus azospirillium. Israel J. Bolawy 31: 237-245. 
Bonner, E.R., Cahoon, R.E., Knapke, S.M. and Jeiz, J.M. 2005. Molecular basis of cysteine biosynthesis in plants. J. Biol. Chen. 280(46): 38803-38813.

El-Hadaad, M.E., Ishac, Y.Z., Saleh, E.A., ElBorollosy, M.E., Raffar, A.A. and ElDemerdash, M.A. 1986. Comparison of different methods of inoculation with a symbiotic N2fixer on wheat plant. Second conference of the African Association for Biological Nitrogen fixation, 15-19 December, 1996, Cairo. Egypt. Abst. 286 p.

Eweda, W.E. and Viassk, K. 1988. Seed inoculation with Azospirillium brasitensa and Azotobacter chroococcum on wheat and maize growth. Annals Agric. Sci., Fac. Agric. Ain Shams Univ., 33: 833-856.

Favilli, F., Balloni, W., Cappellini, A., Granchi, L. and Savoini, G. 1987. Esperienze pluriennadi di batteizzazione campo con Azaspirilillum spp. Di coltore cereasicole (long term field experiments Azospirillum Spp. On cereal crops. Annuls of Microbiology 37: 169-181.

Haas, F.H., Heeg, C., Queiroz, R., Bauer, A., Wiritz, M. and Hell, R. 2008. Mitochondrial serine acetyl transference functions as a pace marker of cysteine synthesis in plant cells. Plant Physiol., 148: 1055-1067.

Hassanien, M.S. 2001. Effect of variety and nitrogen levels on growth, yield and yield components of wheat (Triticum aestivum, L.) in newly cultivated land. Egypt. J. Agro. 33: 111-113.
Hussein, A., Rashid, M. and Yassin, M. 1987. Advantages of FYM and its better use. Zarate Nama Lahore 33: 17-18.

Malik, K.A. and Bilal, R. 1988. Survival and colonization of inoculation bacteria in kallar grass rhizosphere and quantification of N2-fixation. Plant and Soil, 110: 329-338.

Mandour, M.S., El-Sherbeiny, S., Batros, N.B. and El-Nagar, S.H. 1986. Effect of nitrogen application upon growth, oil and nutrient content of citronella grass. Bull. Egypt, Soc. Physiol. Sci., 6(3): 145.

Noctor, G. and Foyer, C.H. 1998. Acerbate and glutathione: keeping active oxygen under control. Ann. Res. Plant physiol. Plant Mol. Biol., 49: 249-279.

Snedecor, G.W. and Cochran, W.G. 1981. Statistical Methods, Seventh Edition, Ames, IA: lowa State Univ., USA.

Zaki, R.N. and Radwan, T.E. 2011. Improving wheat grain yield and its quality under salinity conditions at a newly reclaimed soil by using different organic sources as soil or foliar applications. J. Appl. Sci. Res., 7(1): 42-45.

Zheng, Y., Wang, Z., Sun, X., Jia, A., Jiang, G. and $\mathbf{L i}, \mathbf{Z}$. 2008. Higher salinity tolerance cultivars of winter wheat relieved senescence reproductive stage. Eniviron. and Exper. Bot., 62: 129-138. 